\author{
St udia Philosophica \\ Wrat is l a vi e n s i a \\ vol. XV, fasc. $2(2020)$ \\ https://doi.org/10.19195/1895-8001.15.2.10
}

JOANNA GIEL

ORCID: 0000-0003-0436-7179

Uniwersytet Wrocławski

\title{
Literatura jako poszukiwanie prawdy. Poetyka Gottholda Ephraima Lessinga
}

\author{
Literature as a Search for the Truth. \\ The Poetry of Gotthold Ephraim Lessing
}

\begin{abstract}
The aim of the article is to show the significant change in the reflections of art and literature due to Gotthold Ephraim Lessing (1729-1781). It consists of three essential parts. Firstly, I present the historical and philosophical context which influenced Lessing's point of view on art and literature. Secondly, according to Lessing's theoretical writings, I move on to the most important aspects of his poetry, which are inter alia the liberation of the scheme of French classicism and the approach to Greek antiquity. Theory and practice were for Lessing closely connected. Therefore I establish in the third part of the article examples of Lessing's domestic tragedies in which the author fulfils the scheme he presented in theoretical writings.
\end{abstract}

Keywords: Gotthold Ephraim Lessing, domestic tragedies, the theory of dramas, the national theatre, the Enlightenment

Gotthold Ephraim Lessing (1729-1781) wprowadził całkowicie nowy rodzaj refleksji o sztuce i literaturze, istotny przede wszystkim dla dramatu. Odszedł on od poetyk sformułowanych i zwrócił się ku estetyce iluzyjności, zgodnie z którą dramaturg miał nie tylko stosować zasadę mimesis (materia akcji), lecz także zasadę iluzji (prawdopodobieństwo akcji). Celem niniejszego artykułu jest ukazanie radykalnej zmiany, jaka dokonała się za sprawą Lessinga w teorii sztuki i literatury. Ów przełom oznaczał przede wszystkim opozycję względem dominujaccej dotychczas tradycji francuskiej, która z kolei szukała swoich estetycznych korzeni 
w tradycji rzymskiej, oraz zwrócenie się ku estetycznej spuściźnie klasycznej Grecji. W artykule posługuję się teoretycznymi pismami Lessinga oraz nawiązuję do jego tekstów dramatycznych, będących realizacją założeń teoretycznych w praktyce. Argumentuję, że literatura stanowiła dla Lessinga rodzaj poszukiwania prawdy, a nie głoszenia prawdy autorytarnej; tezę tę wspieram przykładami zaczerpniętymi z jego dzieł. Twierdzę również, że w tym tkwi ponadczasowość dokonań Lessinga, które warto przywołać zwłaszcza w kontekście późniejszych teorii przypisujących literaturze wymiar ideologiczny.

\section{Tło historyczno-filozoficzne}

Wspólny mianownik myśli Lessinga z zakresu teorii sztuki i literatury stanowi krytyka racjonalizmu wczesnego oświecenia. Źródeł filozofii racjonalistycznej należy szukać już w dziełach Kartezjusza, następnie kontynuację idei kartezjańskich znajdziemy u Leibniza, który z kolei stworzył podwaliny matematycznie ugruntowanego racjonalizmu Christiana Wolffa. Te wzajemne wpływy, daleko idace nawiązania i trwające dziesiątki lat kontynuacje doprowadziły w I połowie XVIII wieku do ukonstytuowania się racjonalistycznej poetyki Johanna Christopha Gottscheda, będącego notabene uczniem Wolffa. Nie sposób tutaj opisać rozwoju i transformacji racjonalizmu niemieckiego. Poprzez przywołanie tych kilku nazwisk chodzi jedynie o ukazanie pewnego złożonego procesu myśli, jaki doprowadził do sformułowania poetyki noszącej wyraźne piętno racjonalizmu — poetyki normatywnej, ustalającej dla każdej formy literackiej zespół koniecznych reguł.

Połowa XVIII wieku przyniosła pewne pęknięcie: w Listach dotyczaccych najnowszej literatury Lessing postawił pytanie o sens reform Gottscheda, określając idee nie jako reguły, lecz jako fermenta cognitionis ${ }^{1}$. W tym miejscu należy odnotować, iż Lessing poszedł drogą przygotowaną przez Johanna Jacoba Bodmera oraz Johanna Jacoba Breitingera. Wchodząc w spór z lipskim teoretykiem, Szwajcarzy zapoczątkowali nową tendencję rozwojową w sferze refleksji o sztuce i literaturze w obrębie niemieckiego oświecenia. Obok poetyki normatywnej z racjonalistycznie ugruntowanym programem pojawiła się poetyka dowartościowująca fantazję oraz imaginację, co nie tylko uwalniało pisarzy z dotychczasowych więzów retoryki, lecz także otwierało przed nimi możliwość nowej, subiektywnej ekspresji poetyckiej.

Proces ten należy postrzegać w ścisłym związku z narodzinami ogólnej teorii piękna - estetyki, która zdominowała refleksję o sztuce w II połowie XVIII wieku. Wówczas, za sprawą Alexandra Gottlieba Baumgartena, nastąpiło stopniowe rozejście się poetyki od teorii. Począwszy od Arystotelesa, wiedzą teoretyczną na temat literatury zajmowała się dyscyplina zwana poetyką. Dopiero Baumgarten oddzielił poetykę jako praktyczną wiedzę o sposobach przedstawiania i warsztacie analitycznym od estetyki jako bardziej abstrakcyjnej i filozoficznej nauki o postrzeganiu przedmiotów pięknych ${ }^{2}$. Jako pierwszy sformułował on postulat estetyki jako nauki o poznaniu zmysłowym. Stał na stanowisku, że poznania piękna nie

\footnotetext{
${ }^{1}$ C. Karolak, W. Kunicki, H. Orłowski, Dzieje kultury niemieckiej, Warszawa 2007, s. 177.

${ }^{2}$ Zob. A. Burzyńska, M.P. Markowski, Teorie literatury XX wieku, Kraków 2009, s. 18-19.
} 
da się zrealizować za pomocą narzędzi rozumu. Był także przekonany, iż dzieła sztuki są konkretne i indywidualne i dlatego też — jak wnioskował dalej — nie mogą być tworzone według abstrakcyjnych i ogólnych reguł. Formułując postulat estetyki sensualistycznej, Baumgarten zapoczątkował proces, który z końcem wieku XVIII przyniósł negację dualizmu kartezjańskiego. Przekonanie, iż człowiek jako nieszczęśliwa istota złożona z dwóch pierwiastków: ciała i ducha przegrywa wewnętrzną walkę, ulegając temu pierwszemu, straciło legitymację. Nastąpiła rehabilitacja zmysłowości, która nie miała już powodu, aby „wstydzić się" przed rozumem. Warunki ku temu stworzyli przede wszystkim brytyjscy filozofowie, zwłaszcza Anthony Shaftesbury, którego teoria moral sense przypisywała człowiekowi wrodzoną moralność, mającą odtąd stanowić jego naturalny sposób zachowania ${ }^{3}$.

Dla rozwoju tragedii mieszczańskiej Lessinga znaczenie miało także nowe rozumienie komedii, jakie w połowie XVIII wieku sformułował Christian Fürchtegott Gellert (1715-1769). Swoją koncepcję komedii wyłożył on w rozprawie napisanej z okazji objęcia przez niego profesury na Uniwersytecie w Lipsku: Pro commedia commovente (1751), którą Lessing notabene przetłumaczył na język niemiecki. Gellert broni tutaj comédie larmoyante, odwołując się do Pameli (1743) Nivelle'a de la Chaussée'a. Utwór ten był dramatyczną wersją angielskiej powieści Richardsona (1689-1761), w której autor ukazywał człowieka w jego stosunku do porządku obyczajowego. Gellert rozróżnia w swej rozprawie zabawną i poważną komedię, przypisując pierwszej obnażanie słabości, a drugiej przedstawianie cnoty. Ukazanie cnoty, która ostaje się wystawiona na próbę, jest jego zdaniem cenniejsze niż satyryczna uciecha, a współczujące łzy bardziej spełniają dydaktyczno-moralny cel komedii niż rubaszny śmiech. Gellert, w przeciwieństwie do jemu współczesnych, nie chciał satyrycznie przedstawiać i wyśmiewać błędów i słabości ludzkich. Cenniejsze oddziaływanie miało w jego rozumieniu ukazanie wzorców pozytywnych, co pozwala na zestawienie jego zapatrywań z poglądami jezuitów ${ }^{4}$. Gellert rezygnuje z rubasznego humoru, a jego komedie stają się „budującymi traktatami moralno-dydaktycznymi"5. Komedia Gellerta przestaje być komiczna, a jej celem staje się wywołanie u widza sympatii wobec moralnie wartościowego bohatera, współodczuwania z jego losem, radosnego uniesienia, gdy ten zachowuje swą cnotę. W ten sposób komedia Gellerta utorowała drogę ku tragedii mieszczańskiej Lessinga.

Lessing przybył do Lipska, by zgodnie z zaleceniem rodziców studiować teologię. Lipsk, będąc wówczas jednym z najbogatszych i najbardziej nowoczesnych miast niemieckich, stanowił istotny ośrodek uniwersytecki. Professor ordinarius publicus Gottsched nadawał ton ówczesnej literaturze niemieckiej, a jego współpraca z grupą teatralną Caroline Neuberin stanowiła pole dla reformy w zakresie teatru i dramatu. Atmosferę Lipska można by określić mianem wczesnej, artystycznej bohemy ${ }^{6}$, której stosunek do świata akademickiego był raczej ambiwa-

${ }^{3}$ Zob. J. Sprute, Der Begriff des Moral Sense bei Shaftesbury und Hutcheson, „Kantstudien” 71 (1980), s. 221-237.

${ }^{4}$ Zob. O. Mann, Geschichte des deutschen Dramas, Stuttgart 1963, s. 153.

${ }^{5}$ Zob. H. Prang, Geschichte des Lustspiels. Von der Antike bis zur Gegenwart, Stuttgart 1968, s. 147.

${ }^{6}$ Zob. W. Barner, Lessing als Dramatiker, [w:] Handbuch des deutschen Dramas, W. Hinck (red.), Düsseldorf 1980, s. 108 . 
lentny. Młody Lessing wszedł $\mathrm{w}$ to środowisko, przyjmując z jednej strony coraz bardziej krytyczną pozycję wobec normatywnej poetyki uniwersyteckich uczonych, a z drugiej - korzystając z wolności akademickiej, która otworzyła przed nim możliwość literackiej aktywności. Niepowtarzalność lipskich konstelacji spowodowała, że Lessing — opierając się na protestancko-naukowym fundamencie — już wkrótce stał się wolnym i niezależnym pisarzem. Po przeniesieniu się do Berlina w 1747 roku zachował świadomy dystans wobec świata akademickiego. W Berlinie, oddalony przede wszystkim od bezpośredniego wpływu Gottscheda, kontynuował krytyczno-teoretyczną refleksję, by dokonać niebawem przełomu w obszarach, które stanowiły środek ciężkości epoki oświecenia: począwszy od estetyki jako ogólnej teorii sztuki, przez krytykę literacką, a skończywszy na dramacie mieszczańskim i teatrze narodowym.

\section{Poetyka Lessinga w teorii}

We wskazanym kontekście teorii literacko-filozoficznych należy postrzegać dokonania Lessinga. Nie był on samotną wyspą, a jego poglądy na sztukę i literaturę wykształciły się w duchu i na tle epoki, w której żył. U Lessinga zmiana konwencji w myśleniu estetycznym wynikała przede wszystkim ze zmiany kierunku literackich inspiracji. Podczas gdy Gottsched nawiązywał do regularnego teatru francuskiego - był inspiratorem przekładów dzieł takich dramatopisarzy, jak Corneille, Racine, Moliere, oraz autorem pierwszego oryginalnego dramatu w stylu francuskim Sterbender Cato (1732) — tak Lessing wskazał na nowy obszar poetyckich inspiracji, czyli tradycję angielską. Polemika z Gottschedem w tym aspekcie dochodzi do głosu zwłaszcza w siedemnastym Liście dotyczacym najnowszej literatury z 16 lutego 1759 roku. Lessing pisze: „[Gottsched] chciał nie tyle poprawić nasz stary teatr, ile być twórca całkiem nowego. I to jakiegoż nowego? Francuskiego, nie analizując, czy ów francuski teatr będzie odpowiadał niemieckiemu sposobowi myślenia, czy tė̇ nie”" Tak brzmi alternatywa według Lessinga: „Jeśli przetłumaczyć naszym Niemcom, ze skromnymi zmianami, mistrzowskie dzieła Szekspira, to - jestem pewien - miałoby to lepsze skutki niż te znane jako Corneille oraz Racine" . Różnicę między sztuką dramatyczną Francuzów a Anglików Lessing oddaje następującymi słowami: „Anglik osiąga cel tragedii prawie zawsze, nawet jeśli wybiera dziwne i sobie właściwe drogi, a Francuz nie osiąga go prawie nigdy, nawet jeśli podąża drogami utartymi w antyku"'.

Lessing przyczynił się do wyparcia tradycji francuskiej przez angielską, zwłaszcza w obrębie niemieckiej sztuki dramatycznej. Podczas gdy francuscy teoretycy odwoływali się do tradycji rzymskiej, angielscy i niemieccy estetycy szukali korzeni w klasycznej Grecji. Ta zmiana paradygmatu przebiegała równolegle w różnych

${ }^{7}$ G.E. Lessing, Briefe, die neueste Literatur betreffend, 17. Brief vom 16.02.1759, [w:] idem, Literaturtheoretische und ästhetische Schriften, A. Meier (red.), Stuttgart 2006, s. 36 (fragmenty dzieł Lessinga przytaczane są w artykule w przekładzie jego autorki).

8 Ibidem, s. 36.

${ }^{9}$ Ibidem, s. 37. 
obszarach sztuki i literatury. Podkreślanie znaczenia studiowania sztuki antycznej łączyło Lessinga z Johannem Joachimem Winckelmannem. W niewielkim, ale bardzo ważnym traktacie o programowym tytule Gedanken über die Nachahmung der griechischen Werke in der Malerey und Bildhauerkunst (1755) Winckelmann postulował specyficzne naśladowanie starożytnych, to jest takie, które pozwoli na stworzenie sztuki niemożliwej do naśladowania. Tym samym teoretyk zdystansował się od prostej zasady mimesis, wzywając jednocześnie do produktywności, kreatywnego tworzenia. Odwołując się do starożytnych źródeł, Winckelmann sformułował hasło dla klasycznego piękna: ,szlachetna prostota i cicha wielkość”, które stało się myślą przewodnią klasyki weimarskiej.

Teorie estetyczno-literackie w II połowie XVIII wieku charakteryzuje współistnienie dwóch tendencji, w których to różnice stały się ważniejsze niż podobieństwa. Chodzi o zróżnicowanie w obrębie poszczególnych dziedzin sztuki oraz w obszarze kultur narodowych. Do rozwoju obu tych tendencji Lessing walnie się przyczynił. Po pierwsze, poprzez traktat Laokoon, w którym wytyczył granice poszczególnych sztuk ze względu na charakter ich tworzywa oraz na sposób przyporządkowania znaków, jakimi się posługują ${ }^{10}$; po drugie, poprzez swą krytyczną działalność przy hamburskim teatrze narodowym, utworzonym w 1766 roku przez Johanna Friedricha Löwena. Celem tej sceny było propagowanie sztuk niemieckich, na aktorskim i reżyserskim poziomie odpowiadającym scenom francuskim i angielskim ${ }^{11}$. Lessing, począwszy od roku 1767, kiedy Löwen ściągnął go do Hamburga, wnikliwie obserwował wydarzenia przy hamburskim Gänsemarkt. Na podstawie tych obserwacji powstało jego najważniejsze dzieło teoretyczne z zakresu teatroznawstwa Hamburgische Dramaturgie - publikowane cotygodniowo odcinkami w czasopiśmie, które Lessing wydawał wraz z Johannem Bode w drukarni specjalnie założonej w tym celu w Hamburgu.

Właściwym dla Hamburgische Dramaturgie jest wzajemne przenikanie się refleksji teoretycznej oraz praktyki dramaturgicznej. Lessing nie rozwija tutaj systematycznej teorii dramatycznej; jego dzieło nie jest zbiorem reguł obowiązujaccych dla tworzenia literatury, a raczej stanowi krytyczną refleksję na temat praktyki teatralnej. Autor nie ocenia literatury według utartych reguł, lecz odwrotnie to poszczególne teksty stają się dla niego przedmiotami analiz, z których mogą, ale nie muszą zostać wyprowadzone prawa ogólniejsze. Taki sposób postępowania przywodzi na myśl metodę indukcyjną, obowiązującą w naukach przyrodniczych ${ }^{12}$. Krytyczna metoda Lessinga wychodzi bowiem od jednostkowej obserwacji, by uczynić przedmiotem analiz całość zjawisk teatralnych, począwszy od wydarzeń na scenie, poprzez status aktora i sztuki aktorskiej, preferowanych wzorców, a skończywszy na recepcji i odbiorze ze strony publiczności.

Celem metody Lessinga, polegającej przede wszystkim na subiektywnej polemice z francuskimi teoretykami, było rozpoznanie tego, co błędne. To z kolei miało

10 Zob. C. Karolak, W. Kunicki, H. Orłowski, Dzieje kultury niemieckiej, s. 178.

11 Ibidem, s. 184.

12 W. Barner, G.E. Grimm, H. Kiesel, M. Kramer, Lessing. Epoche - Werk - Wirkung, München 1998, s. 186 . 
stanowić warunek poznania tego, co prawdziwe. Podobne krytyczne postępowanie można znaleźć u Arystotelesa, na którego Lessing niejednokrotnie się powoływał. Arystoteles był dla Lessinga autorytetem, choć nie niepodważalnym. Autor Hamburgische Dramaturgie akceptował twierdzenia zawarte w Poetyce, ale jednocześnie poddawał je krytycznej weryfikacji, konfrontując z rzeczywistością współczesnego mu teatru. Lessing zarzucał egzegetom Arystotelesa, że odłączyli Poetykę od empirycznej podstawy, czyli od mistrzowskich sztuk greckiego teatru, czyniąc z niej obowiązujący kanon zasad. Potwierdza to przywołany wcześniej wniosek, iż dla Lessinga teoria szła w parze z praktyką i że według niego reguły miały wynikać z dzieła, a nie dzieło z reguł. Nie znaczy to, że Lessing nie uznawał konieczności zasad, jednakże nie w sensie praw absolutnie obowiązujących, lecz raczej wytycznych, które dramaturg może modyfikować.

Zdaniem Lessinga w Poetyce zostało powiedziane to, co najbardziej wiążące w kwestii greckiej tragedii. To, co wyraził Arystoteles, należało porównać z praktyką greckiego dramatu, by przekonać się o ich wzajemnym potwierdzeniu. Współczesna Lessingowi praktyka estetyczna i literacka nawiązywała do antyku, jednakże dla Lessinga nasuwało się pytanie, czy w tej materii uczyniono wystarczająco dużo. Postawił on sobie jako dwa główne zadania wyzwolenie literatury ze schematu francuskiego klasycyzmu oraz jeszcze większe zbliżenie do greckiego antyku w praktyce.

Począwszy od Arystotelesa, punktem centralnym wszystkich teoretycznych wywodów na temat dramatu było przekonanie, iż tragedia nie jest celem samym w sobie, lecz ma oddziaływać na widza. Zadawano sobie pytanie, w jaki sposób zrealizować najważniejsze zadanie tragedii, czyli przeżycie katartyczne u widza. W tym miejscu zarówno Gottsched (naśladujacc Francuzów), jak i Lessing nawiązywali do arystotelesowego pojęcia phobos jako jednego ze środków do osiągnięcia katharsis, jednakże ich rozumienie tego pojęcia było zasadniczo różne. Podczas gdy Gottsched interpretował phobos jako trwogę związaną z nagłą, fizyczno-psychiczną reakcją, Lessing widział w nim trwogę, która przejmuje naszą duszę (Gemüt), gdy ta obserwuje przedstawioną w tragedii rzeczywistość. Z dzisiejszej perspektywy Gottschedowi przypisuje się rozumienie phobos jako Schrecken, natomiast Lessingowi - jako Furcht, mimo iż początkowo Lessing używał także terminu Schrecken. Aby zobrazować tę różnicę, można posłużyć się pewnym uproszczeniem: trwoga (Schrecken) Gottscheda to ta odniesiona do innych, natomiast trwoga (Furcht) Lessinga jest odniesiona do nas samych. O tym, jak zawiła była dyskusja wokół tłumaczenia tego terminu, świadczy 74 fragment Hamburgische Dramaturgie. Lessing przywołuje tutaj przykład Szekspirowskiego dramatu Ryszard III, by stwierdzić, że jego tytułowy bohater rzeczywiście wywołuje w nim grozę (Schrecken), jeśli rozumieć pod tym pojęciem przerażenie wobec okropnych czynów i dreszcz na widok popełnianych zbrodni. Jednak — jak pisze Lessing — właściwą trwoga jest ta, którą odczuwamy na widok nieszczęścia kogoś podobnego do nas ${ }^{13}$. I właśnie taki rodzaj trwogi kryje się zdaniem Lessinga pod pojęciem arystotelesowego phobos.

${ }^{13}$ Zob. G.E. Lessing, Hamburgische Dramaturgie (74. Stück), [w:] idem, Literaturtheoretische und ästhetische Schriften, s. 146. 
Nowe tłumaczenie arystotelesowego terminu phobos miało służyć jako teoretyczna przesłanka do zniesienia klauzuli stanowej. Zdaniem Lessinga widz musi mieć świadomość, że może stać się uczestnikiem wydarzeń, które ogląda. Dlatego też w Hamburgische Dramaturgie autor postulował styczność tego, co dzieje się na scenie, z życiem odbiorców. W praktyce oznaczało to dwa elementy. Po pierwsze, wprowadzenie na deski teatru niemieckiego całkiem nowego, awansujaccego kulturalnie i ekonomicznie stanu mieszczańskiego. Po drugie, ukonstytuowanie nowego bohatera jako indywiduum, który wyparł typy Gottscheda. Nowy bohater Lessinga nie był ani uosobieniem cnoty, ani skończonym złoczyńcą, lecz miał zarówno pozytywne, jak i negatywne cechy charakteru. Wyparcie herosów klasycznego dramatu nie oznaczało jednak, że u Lessinga nie występowali ,wielcy tego świata". Owszem, jednakże interesowali oni autora tylko jako jednostki ludzkie, z różnymi cnotami, ale i słabościami. Postulat „mieszanych charakterów” Lessing zaczerpnął także od Arystotelesa, jednakże poddał go pewnej modyfikacji, mając na uwadze już nie tylko cel tragedii, polegający na wywoływaniu u widza trwogi i współczucia. Konieczność tego postulatu wynikała również z rozumienia przez Lessinga zasady mimesis - poeta, którego zadaniem jest naśladowanie wszelkiego stworzenia, musiał nadać swojemu dramatycznemu modelowi odpowiedni stopień prawdopodobieństwa.

Dzięki tym dwóm elementom — wprowadzeniu do dramatu bohatera mieszczańskiego oraz kreacji mieszanych charakterów - Lessing umożliwił widzowi afektywną (stanową i charakterologiczną) identyfikację z postaciami tragedii, która stała się warunkiem przeżycia katartycznego. Zdaniem autora Hamburgische Dramaturgie ważniejsze od trwogi i grozy było współczucie (Mitleid) wobec nieszczęścia bohatera. Swoje rozumienie tego pojęcia Lessing wyłożył w przywołanym już 74 fragmencie Hamburgische Dramaturgie poprzez nawiązanie do definicji Mosesa Mendelssohna: współczucie jest doznaniem składającym się z miłości do obiektu, jak i niezadowolenia spowodowanego jego nieszczęściem ${ }^{14}$. W ten sposób Lessing przeniósł katharsis, traktowane do tej pory jako akt racjonalny, do sfery emocjonalnej. We współczuciu upatrywał Lessing podstawę wszelkich cnót człowieka: człowiek współczujący to człowiek cnotliwy. Powołując się na Arystotelesa i przedstawiając taką interpretację jego założeń, Lessing nazywa współczucie i trwogę warunkami przeżycia katartycznego, przypisując jednocześnie pierwszemu uczuciu wartość nadrzędną: „Arystoteles nie rzekłby: współczucie i trwoga, jeśli pod pojęciem trwogi nie rozumiałby po prostu modyfikacji współczucia"15. Tym samym autor Hamburgische Dramaturgie przeformułował zasadniczą funkcję tragedii — ma ona w pierwszej kolejności poruszać (erregen), a nie oddziaływać w sposób moralnie dydaktyczny, jak twierdził Gottsched.

O tym, że Lessing przeniósł środek ciężkości dramatycznych inspiracji z teatru francuskiego na teatr angielski, była już mowa. W 70 fragmencie Hamburgische Dramaturgie autor powołuje się także na dramat hiszpański, jeszcze bardziej odległy niemieckiemu odbiorcy niż dramat angielski. Jako wzorzec zostaje przywołany

\footnotetext{
14 Ibidem, s. 148.

15 Ibidem.
} 
król hiszpańskiego dramatu — Lope de Vega, który łącząc tragizm z komizmem, wyszedł naprzeciw oczekiwaniom ludu. Lessing zauważa, że teatr hiszpański nie dał się wtłoczyć w mechaniczne reguły francuskiego klasycyzmu. Hiszpańskie połączenie tego, co poważne, i tego, co zabawne, wydaje mu się nieodzowną koniecznością nie tylko dlatego, że oczekuje tego publiczność, lecz także dlatego, że tak uczy natura. Powoływanie się na naturę w kwestiach gatunkowych pokazuje z jednej strony, jak silny wpływ na poetykę miał w XVIII wieku rozwój nauk przyrodniczych. Z drugiej strony prowadzi do zasady mimesis - centralnego pojęcia poetyk choćby Platona i Arystotelesa - która na nowo odżywa w estetyczno-literackich teoriach XVIII wieku, a więc również u Lessinga. W Hamburgische Dramaturgie autor trzyma się zasady naśladowania natury, która jest dla niego nie tyle podstawą systemu poetologicznego, ile raczej opisem estetycznej relacji między rzeczywistością a fikcją literacką ${ }^{16}$. W przywołanym wcześniej 70 fragmencie pojęcie natury ulega rozszerzeniu — chodzi nie tylko o „naturę zjawisk”, lecz także o ,naturę naszych doznań i sił duszy"17. Elementy wywiedzione z natury muszą zostać połaczone z sobą w taki sposób, aby powstał związek przyczynowy. Na tym polega zadanie sztuki - aby zmysłowo unaocznić to, co w rzeczywistym życiu jest możliwe, jako akt intelektualny.

\section{Poetyka Lessinga w praktyce}

W ten sposób Lessing pozyskał wytyczne również dla własnej twórczości dramatycznej. Jego pierwszą tragedią mieszczańską jest napisana w 1755 roku Miss Sara Sampson. Demonstrując tragiczny fatalizm losu swoich bohaterów, Lessing wywołuje u odbiorcy trwogę oraz współczucie. Jednocześnie dokonuje głębokiego wglądu w naturę człowieka, pokazując ludzkie zaślepienie. Mellefont i Marwood ucieleśniają sferę popędliwości i namiętności, która sprzeniewierza się Boskiemu zamysłowi i która jest przyczyną nieszczęścia dla otoczenia. Wiążące dla Lessinga staje się tutaj religijne stanowisko, które we francuskim klasycyzmie oraz u Gottscheda ustąpiło miejsca autonomicznej moralności człowieka. Lessing wychodzi poza tę moralność, ukazując, że człowiek — pomimo danej mu siły rozumu — nie potrafi uchronić się od konfliktowych sytuacji. Te prowadzą do katastrofy i dopiero w momencie klęski człowiek, rozpoznając własną słabość, wyzwala się ku wolności. Miss Sara Sampson wskazuje na nawiązanie Lessinga do dramatu angielskiego, gdyż inspiracją dla jej powstania była tragedia George'a Lillo The London Merchant (1731).

Niewątpliwym ukoronowaniem poglądów Lessinga na istotę dramatu jest Emilia Galotti (1772), najświetniejsze dzieło tragedii mieszczańskiej w Niemczech. Lessing — ukazując różnice strukturalne, jak i egzystencjalne między warstwą mieszczańską (którą reprezentuje przede wszystkim Emilia i jej ojciec) a dworską (książę) - zwraca się przeciwko zachowaniu i postawie przedstawicieli arysto-

${ }^{16}$ Zob. W. Barner, G.E. Grimm, H. Kiesel, M. Kramer, Lessing. Epoche - Werk - Wirkung, s. 192.

17 G.E. Lessing, Hamburgische Dramaturgie (70. Stück), [w:] idem, Literaturtheoretische und ästhetische Schriften, s. 144. 
kracji. Tym samym wpisuje się w charakterystyczne dla II połowy XVIII wieku tendencje inteligencji mieszczańskiej, która rozwijała pojęcia skierowane przeciw dworskiej warstwie wyższej. Polem dla krytyki była przede wszystkim odmienność w sposobie bycia i zachowania, w życiu codziennym, aspiracjach i moralności. Występowano przeciwko takim cechom ludzkim, jak nieszczerość, powierzchowność. Walka awangardy stanu średniego — mieszczańskiej inteligencji — przeciwko warstwie dworskiej rozgrywała się prawie całkowicie poza sferą polityczną. Obszar, na którym była realizowana, stanowiła przede wszystkim literatura. Powstające wówczas utwory, w których dochodziła do głosu krytyka wobec przywilejów społecznych arystokracji, ale też wobec postawy jej przedstawicieli, cieszyły się wielką poczytnością ${ }^{18}$.

W dramacie Emilia Galotti Lessing stawia pod znakiem zapytania oświeceniowe pojęcia cnoty i wady. Czy oświeceniowy fundamentalizm moralny nie tłamsi naturalnej reakcji człowieka? Emilia — zawieszona pomiędzy cnotą a słabością, świadoma swej skłonności do bycia uwiedzioną - chce umrzeć, by bronić swej cnoty za wszelką cenę. Prowokuje ojca, by ją zabił, gdyż obawia się, że nie pozostanie nieugięta wobec uwodzicielstwa księcia. Wskazując na radykalizm Emilii — który jest tak silny, że bohaterka poświęca wszystko - Lessing pokazuje kryzys oświeceniowego systemu wartości opartego na czarno-białym rozróżnieniu cnoty i wady. Śmierć Emilii to nie histeria emocjonalna, lecz histeria oświeceniowego moralizmu. Emilia Galotti to próba dotarcia do prawdy o człowieku i tym samym odejście od oświeceniowej pewności moralnego fundamentalizmu. W tragedii tej Lessing zastępuje „dogmatyczną formę pouczenia”, jaka dotychczas panowała w dramacie niemieckim, luźniejszą formą dyskusji i dedukcji. Pewność prawdy autorytarnej ustępuje miejsca poszukiwaniu prawd alternatywnych, zgodnie ze słynnym zdaniem:

Gdyby Bóg w swej prawicy dzierżył wszelaką prawdę, a w lewicy nieustający popęd zdobywania prawdy, w połączeniu nawet z koniecznością nieustannych i wiecznych omyłek, i gdyby rzekł do mnie: wybieraj! Wówczas z pokorą chwyciłbym jego lewicę, mówiąc: Ojcze, daj! Czysta prawda jest wszak tylko dla Ciebie! ${ }^{19}$

Dramatyczna twórczość Lessinga to przykład twórczości protestancko-chrześcijańskiej, w której ogląd i ważność zyskiwało najgłębsze religijne przekonanie. Potwierdza to także dramat Natan Mędrzec (1779). Poemat dramatyczny w pięciu aktach - tak brzmi podtytuł tego utworu, sytuujący go w przestrzeni międzygatunkowej. Natan Mędrzec to historyczny dramat rodzinny, składający się zarówno z elementów właściwych dla tragedii, jak i komedii, co w pełni odpowiadało postulatom Lessinga wyłożonym w rozprawie Abhandlungen von dem weinerlichen oder rührenden Lustspiele (1754). Posłużenie się specyficznym gatunkiem mogłoby sugerować niesceniczność Natana. W istocie — w pierwotnym założeniu dramat ten był pisany z myślą o oddziaływaniu nie tyle teatralnym, ile światopoglądowym. Lessing był głęboko zaangażowany w spór teologiczny z pastorem z Hamburga

18 Zob. N. Elias, Przemiany obyczajów w cywilizacji Zachodu, Warszawa 1980, s. 35-44.

${ }^{19}$ G.E. Lessing, Eine Duplik, [w:] idem, Gesammelte Werke in zehn Bänden, t. 8. Philosophische und theologische Schriften, Berlin 1956, s. 24-108, tu: s. 27 (polskie tłumaczenie za: C. Karolak, W. Kunicki, H. Orłowski, Dzieje kultury niemieckiej, s. 177-178). 
Johannem Melchiorem Goeze, znanym w literaturze jako spór o fragmenty. Punktem zapalnym tego sporu było anonimowe wydanie przez Lessinga pism Reimarusa (Fragmente eines Ungenannten), opatrzone autorskim komentarzem. Zdaniem Goezego, z perspektywy luteranizmu, publikacja Lessinga stanowiła herezję, gdyż autorzy próbowali w niej wykazać, że ani Stary, ani Nowy Testament nie moga rościć sobie prawa do treści objawionych. Spór o fragmenty rozgrywał się na gruncie teoretycznym i literackim. Lessing opublikował w sumie 11 pism polemicznych, znanych w literaturze jako „Anti-Goeze”. W konsekwencji w lipcu 1778 roku książę brunszwicki zakazał mu kontynuowania sporu o fragmenty. Lessing w liście do Elise Reimarus napisał wówczas: „Muszę spróbować, czy pozwoli mi się, nie zakłócając mnie, głosić kazania z mojej starej ambony — w teatrze" ${ }^{\text {20 }}$. Tak też Lessing przeniósł spór o fragmenty na grunt literacki, pisząc Natana Mędrca, którego Friedrich Schlegel określi później jako „die Fortsetzung vom Anti-Goeze, Numero Zwölf”21.

Opowieść Natana o mężu, który posiadał pierścień „miły Bogu i ludziom” i który zlecił sporządzenie dwóch pierścieni, by móc nimi obdarować każdego ze swoich trzech synów, ma głęboką wymowę religijną. Ojciec symbolizuje Boga, natomiast pierścień - religię. Ojciec ofiarujący pierścień to Bóg darujący religię. Trzy pierścienie jako trzy religie monoteistyczne odnoszą się do tej samej tajemnicy objawienia, w której wielbiony jest jeden i ten sam Bóg. Lessing zdawał sobie zapewne sprawę z historycznych uwarunkowań religii monoteistycznych — jawiły mu się one jako niedoskonałe fenomeny religii powszechnej. Dlatego tė̇ stał na stanowisku, że religie monoteistyczne muszą się nawzajem tolerować, gdyż żadna z nich nie posiada wiążącej prawdy wyższej. Spór między synami, który z pierścieni jest autentyczny, to ukryte pytanie Lessinga o kryterium wartości religii. W słowach sędziego, który rozstrzyga spór, dochodzi do głosu przekonanie Lessinga, iż tym kryterium ma być wymierna dobroć etyczna wyznawców. Każdy posiadacz pierścienia powinien bowiem dowieść jego tajemniczej siły, urzeczywistniając w swym religijnym dążeniu najważniejsze przykazanie Boże: przykazanie miłości. A zatem to nie kult, lecz miłość — jako podstawa wszelkich dobrych czynów i prawdziwej tolerancji — stanowi centralny nakaz religijny.

Natan Mędrzec to głos Lessinga w sporze między nowoczesną teologią oświeceniową a ortodoksją luterańską. Z jednej strony Lessing przeciwstawiał się współczesnym mu dążeniom do redukcji rzeczywistości Boga do tego, co ludzkie, i do ukonstytuowania religii naturalnej. Z drugiej jednak strony nie identyfikował się także z ortodoksją luterańską, która w jego opinii tak naprawdę osłabiała chrześcijaństwo. Z uwagi na swoje śmiałe poglądy, niemieszczące się w ramach protestanckiej ortodoksji, Lessing był traktowany bardzo podejrzliwie i z niechęcią w kręgach kościelnych. Ten nieprzychylny wizerunek pogłębiła wiadomość podana przez Friedricha Heinricha Jacobiego, iż Lessing wyznał mu swój spinozyzm. Utożsamienie z czymś, co było powszechnie potępiane i postrzegane za coś bardziej szkodliwego aniżeli ateizm, spowodowało, że Lessing stracił niezmiernie dużo w oczach tych, którzy widzieli w nim człowieka oświecenia. Głównym antagonistą Jacobiego

${ }^{20}$ Cyt. za: W. Barner, Lessing als Dramatiker, s. 119.

${ }^{21}$ Zob. R. Smend, Gotthold Ephraim Lessing, [w:] Gestalten der Kirchengeschichte, t. 8. Die Aufklärung, M. Greschat (red.), Stuttgart-Berlin-Köln-Mainz 1983, s. 291. 
w sporze o spinozyzm Lessinga stał się Moses Mendelssohn, serdeczny przyjaciel Lessinga, który zresztą został wzorcem dla kreacji postaci Natana Mędrca. Warto nadmienić, że Lessing w lipcu 1779 roku przesłał Jacobiemu swój dramat z bilecikiem „Autor Natana Mędrca z przyjemnością chciałby odwdzięczyć się za pouczajacce i wypełnione emocjami godziny, które ten mu sprawił"22.

Do spotkania Jacobiego i Lessinga doszło dwukrotnie w 1780 roku, z inicjatywy pierwszego. Relację z tych spotkań i z wyznania Lessinga, które stało się powodem zawiązania po kilku latach kontrowersyjnego sporu o Spinozę, znajdujemy w piśmie Jacobiego O nauce Spinozy w listach do Pana Mojżesza Mendelssohna (Über die Lehre des Spinoza in Briefen an Herrn Moses Mendelssohn). Czynnikiem wyzwalającym wyznanie Lessinga miał być pokazany mu przez Jacobiego wiersz Prometeusz Goethego. Choć utworu genialnego poety nie można nazwać w pełni panteistycznym, to jednak stanowisko Goethego znacząco zbiega się tutaj z ujęciem Spinozjańskim - to radykalne pożegnanie z tradycyjnym i najbardziej rozpowszechnionym obrazem Boga ${ }^{23}$. Jak relacjonuje Jacobi w liście do Mendelssohna z 4 listopada 1783 roku, Lessing miał powiedzieć, iż zawarty w wierszu punkt widzenia jest jego własnym i że nie zna nikogo innego poza Spinozą, czyje poglądy bardziej ujawniałyby jego własne zapatrywania ${ }^{24}$. Wraz z publikacją tekstów Jacobiego O nauce Spinozy... prowadzony do tej pory listownie spór Jacobiego i Mendelssohna o spinozyzm Lessinga stał się publiczny, a rozstrzyganie tej kwestii doprowadziło do istotnej debaty wokół filozofii Spinozy, która miała zasadniczy wpływ na przemiany niemieckiej filozofii w ostatnich dziesięcioleciach XVIII wieku.

\section{Konkluzja}

Żeby uzmysłowić sobie zasługi Lessinga, należy mieć na uwadze stan refleksji o sztuce i literaturze niemieckiej w momencie, gdy autor formułował swoje pierwsze estetyczne poglądy. W praktyce królował dramat według wzorca francuskiego, który w samej Francji okres świetności miał już za sobą. Powszechne teorie estetyczne, na które wpływ miały racjonalizm i empiryzm, charakteryzował chaos. Można powiedzieć, że Lessing stanął w obliczu sytuacji, którą później (około 1800 roku) zobrazował Friedrich Schlegel: poprzez fałszywe pojęcia poezja zbłądziła i dlatego słuszne pojęcia muszą ją teraz sprowadzić na właściwą drogę. Gdy Lessing umarł, Johann Gottfried Herder umieścił na początku nekrologu następujące słowa: „Żaden współczesny pisarz, wydaje mi się, nie oddziaływał na Niemcy bardziej w kwestiach smaku oraz podstawowego osądu na temat literackich zdarzeń niż Lessing”25. Wspomniany już Schlegel nazwał natomiast Lessinga „właściwym autorem narodu i epoki"'26.

\footnotetext{
${ }^{22}$ Cyt. za: J. Piórczyński, Spór o panteizm, Toruń 2016, s. 23.

${ }^{23}$ Ibidem, s. 47-48.

${ }^{24}$ Zob. F.H. Jacobi, Werke, t. 4, cz. 1. Über die Lehre des Spinoza in Briefen an Herrn Moses Mendelssohn, Leipzig 1819, s. 54.

25 J.G. Herder, Zerstreute Blätter, 3, „Teuscher Merkur”, Oktober 1781, [w:] S. Seidel, Gotthold Ephraim Lessing 1729-1781. Eine Einführung in sein Leben und Werk, Berlin 1963, s. 172.

${ }^{26}$ Cyt. za: W. Barner, G.E. Grimm, H. Kiesel, M. Kramer, Lessing. Epoche - Werk - Wirkung, s. 94 .
} 
Lata życia Lessinga obejmują niewiele więcej niż pół stulecia, a jednak mogą być traktowane jako przykładowe dla całej epoki oświecenia ${ }^{27}$. Przede wszystkim zbiegają się one z istotnymi wydarzeniami politycznymi XVIII wieku, który był stuleciem rewolucyjnej ideologii mieszczańskiej. Upłynął on w Niemczech pod znakiem historycznych zmagań o ekonomiczną i polityczną pozycję mieszczaństwa, a wzorcem i przykładem były ruchy oświeceniowe zarówno w Anglii, jak i we Francji. Cóż oznaczało „oświecenie”? Oznaczało ono „wyjście z samozawinionej niepełnoletności", zdanie się na rozum, a to z kolei - niepodporządkowywanie się pod żaden autorytet, ani świecki, ani duchowy. Nieoświeceniowe były feudalizm i absolutyzm. Oświeceniowa była natomiast walka o narodową jedność przez wyzwolenie klasy mieszczańskiej. W życiu i twórczości Lessinga odzwierciedlają się te dążenia - reprezentuje on bowiem stanowisko interesu społecznego oraz narodowego. Tragedia mieszczańska może być traktowana jako ukoronowanie dążeń emancypacyjnych tej klasy, a co więcej — jako przyczynek do wykształcenia w czytelniku-widzu świadomości narodowej. Lessing przygotował grunt, na którym później niemiecka klasyka mogła wznieść się ponad obce wzorce ku własnej narodowej samodzielności.

\section{Bibliografia}

Barner W., Lessing als Dramatiker, [w:] Handbuch des deutschen Dramas, W. Hinck (red.), Düsseldorf 1980, s. 106-119.

Barner W., Grimm G.E., Kiesel H., Kramer M., Lessing. Epoche - Werk - Wirkung, München 1998.

Burzyńska A., Markowski M.P., Teorie literatury XX wieku, Kraków 2009.

Elias N., Przemiany obyczajów w cywilizacji Zachodu, Warszawa 1980.

Jacobi F.H., Werke, t. 4, cz. 1. Über die Lehre des Spinoza in Briefen an Herrn Moses Mendelssohn, Leipzig 1819.

Karolak C., Kunicki W., Orłowski H., Dzieje kultury niemieckiej, Warszawa 2007.

Lessing G.E., Literaturtheoretische und ästhetische Schriften, A. Meier (red.), Stuttgart 2006.

Mann O., Geschichte des deutschen Dramas, Stuttgart 1963.

Piórczyński J., Spór o panteizm, Toruń 2016.

Prang H., Geschichte des Lustspiels. Von der Antike bis zur Gegenwart, Stuttgart 1968.

Seidel S., Gotthold Ephraim Lessing 1729-1781. Eine Einführung in sein Leben und Werk, Berlin 1963.

Smend R., Gotthold Ephraim Lessing, [w:] Gestalten der Kirchengeschichte, t. 8. Die Aufklärung, Martin Greschat (red.), Stuttgart-Berlin-Köln-Mainz 1983, s. 281-297. Sprute J., Der Begriff des Moral Sense bei Shaftesbury und Hutcheson, „Kantstudien” 71 (1980), s. 221-237.

\footnotetext{
27 Ibidem, s. 88-90.
} 